\title{
STRUCTURAL INVESTIGATION OF RAW AND MODIFIED GLYCANS BY MALDI-TOF MASS SPECTROMETRY
}

\author{
LORETA-ANDREA BOJIN $^{1 \#}$, MARIUS GEORGESCU ${ }^{1 \#}$, CAROLINA COJOCARU ${ }^{2 *}$, MIHAI-COSMIN \\ PASCARIU ${ }^{2,3}$, VICTOR LORIN PURCAREA ${ }^{4}$, MIHAELA VIVIANA IVAN ${ }^{1}$, MARIA PUIU $^{1}$, \\ CRISTINA DEHELEAN ${ }^{5}$, ALINA-FLORINA SERB ${ }^{1 *}$, EUGEN SISU $^{1}$, MIRCEA N. PENESCU $^{4}$ \\ 1 "Victor Babeș" University of Medicine and Pharmacy Timisoara, Faculty of Medicine, 2 Eftimie Murgu Square, Timișoara, Romania \\ 2 "Vasile Goldiș" Western University of Arad, Faculty of Pharmacy, 86 Liviu Rebreanu Street, Arad, Romania \\ ${ }^{3}$ National Institute of Research \& Development for Electrochemistry and Condensed Matter, 144 Aurel Păunescu Podeanu \\ Street, Timișoara, Romania \\ 4 "Carol Davila" University of Medicine and Pharmacy, 37 Dionisie Lupu Street, Bucharest, Romania \\ 5 “Victor Babeș” University of Medicine and Pharmacy, Faculty of Pharmacy, Department of Toxicology, Timișoara, Romania
}

*corresponding author: aserb@umft.ro

${ }^{\#}$ Authors with equal contribution.

Manuscript received: December 2019

\begin{abstract}
The study of glycans which play essential roles in modulating cell functions, and the elucidation of their pattern variation both in health and disease states, promises to offer new diagnostic options, new bioactive compounds, as well as new targets for glycan-mediated therapeutic interventions enlightening important aspects in the field of 'glycomedicine'. The present paper describes the procedure for obtaining and the analysis of a raw and a modified glycan, respectively. A maltodextrin functionalized with an amine linker is obtained through reductive amination, in the minimum possible number of steps and with the maximum possible yield. The isolation and purification of the basic glycan are also described. The extraction, isolation and purification of a neutral polysaccharide from the fruiting body of Fomes fomentarius by using ion exchange chromatography coupled with dialysis is also presented. Both the natural polysaccharide isolated from the mushroom and the glycan functionalized with hexamethylenediamine (HMD) were analysed by MALDI-TOF mass spectrometry in the positive ion mode. By combining chemical methods, TLC and mass spectrometry, the existence of a Gal ${ }_{x} M n_{y}$ heteropolysaccharide in the Fomes fomentarius neutral polysaccharides was revealed.
\end{abstract}

\section{Rezumat}

În această lucrare este descris procedeul de obținere prin aminare reductivă a unei maltodextrine funcționalizate cu un linker bazic, într-un număr minim de etape și cu randament maxim. Izolarea și purificarea glicanului bazic este de asemenea descrisă. Este detaliată extracția, izolarea și purificarea unei polizaharide neutre din ciuperca Fomes fomentarius prin combinarea cromatografiei cu schimbători de ioni cu dializă cu cernere moleculară. Atât polizaharida naturală izolată din Fomes fomentarius, cât și glicanul funcționalizat cu hexametilendiamina (HMD), au fost analizate prin spectrometrie de masă MALDI-TOF în modul ion pozitiv. Combinând metodele chimice cu cromatografia în strat subțire și spectrometria de masă s-a pus in evidență, în fracțiile polizaharidelor neutre din Fomes fomentarius, existența unui heteropolizaharid de tipul Gal ${ }_{x} \mathrm{Man}_{\mathrm{y}}$.

Keywords: MALDI-TOF, Fomes fomentarius, neutral polysaccharides, hexamethylenediamine

\section{Introduction}

Until present day, a variety of sources have been used for obtaining natural polysaccharides, being widely used as food, pharmaceuticals, medical supplies and paper making.

The most abundant group of biopolymers, i.e. oligosaccharides and polysaccharides, have been identified to be involved in a wide range of biological processes at cellular and molecular levels: embryonic development, cell to cell communication, cellular and humoral immunity, viral and bacterial infection [17]. They are considered superior to other polymers $[10,11]$ due to their bioactivity, biocompatibility, homogeneity, bioadhesive properties, and the ease of use in tailoring [8].
The properties of materials based on polysaccharides can be altered by the introduction of acidic, hydrophobic, basic or other kind of functionality into their structures [6].

Our fundamental understanding regarding the use of their pharmaceutical [12], biocomposite and nanoconjugate potential critically requires a thorough investigation of polysaccharides.

There are many ways to classify polysaccharides, but in respect with their chemical composition, they are divided into two groups, that is homo-polysaccharides (homoglycans), composed of a single type of monosaccharide and hetero-polysaccharides (heteroglycans), constructed from multiple types of monosaccharides. 
Glycoconjugates can also be classified into proteoglycans, glycoproteins and glycolipids depending on the aglycone linked to the glycan [8].

Due to this wide range of structural types, carbohydrate analysis by mass spectrometry can involve numerous techniques, and none of the techniques appears to be ideal for each compound [9].

Matrix-assisted laser desorption/ionization (MALDI) mass spectrometry is a highly versatile choice since most compounds give signals in their native state. MALDI can offer valuable data on various aspects of structural analysis, such as branching, the determination of sequence, and linkage. MALDI is, however, used in combination with one or more chromatographic techniques for further isomer differentiation [9]. To achieve a signal, an analyte must be mixed with a matrix compound and then allowed to crystallize using the solvent evaporation technique, then finally subjected to a laser pulse. Most of the energy of the laser is absorbed by the matrix and transferred to the analyte, which is ionized through alkali metal or proton attachment [13-15]. Careful choice of experimental conditions for measuring mass spectra by soft ionization methods such as MALDI or ESI, allows the sequencing of polymeric materials such as polysaccharides or proteins, by stepwise detachment of their building blocks (monosaccharides or amino acids).

The results obtained by MALDI-TOF MS analysis of the polysaccharide structure modified at the reducing end (hexamethylenediamine functionalized maltodextrin - HDEX), as well as those for a neutral polysaccharide isolated from Fomes fomentarius (FF) are further presented.

\section{Materials and Methods}

\section{Reagents}

All reagents were of analytical grade and were obtained as follows: Dextrin 10 (SERVA - Feinbiochemica Heidelberg/New York), TRIS Hydrochloride (ROTH), sodium hydroxide, phenol (> 99\%) and sulfuric acid 95 - 97\% were purchased from Merck; sodium chloride $99.8 \%$ and ethyl alcohol (abs) were obtained from Chimopar S.A. Bucharest, Romania; hexamethylenediamine (HMD), sodium cyanoborohydride $\left(\mathrm{NaBH}_{3} \mathrm{CN}\right)$ and dimethylformamide (DMF) were all purchased from Aldrich Chemical Co. (Milwaukee, WI, USA) and Sepharose Fast Flow (GE Healthcare Sweden) (Amberlite IR-120) from Sigma (Steinheim, Germany).

The necessary dialysis membranes, molecular weight cut-off $(\mathrm{MW} / \mathrm{CO}=1000)$ were purchased from Spectrum Europe B.V. (Breda, The Netherlands). 2,5-dihydroxybenzoic acid (DHB) $>99 \%$ and 2', 4', ', ' trihidroxyacetophenone monohydrate (THAP) $\geq 99.5 \%$ were acquired from Sigma-Aldrich, (Spruce Street, St. Louis, USA);

Samples

Modified glycan - Dextrin 10 (maltodextrin) was derivatized by reductive amination using hexamethylenediamine (HMD) as an amine component following a slightly modified protocol [18, 21] (Figure 1). Briefly the procedure is: in a $25 \mathrm{~mL}$ round bottom flask with

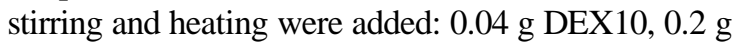
$\mathrm{NaBH}_{3} \mathrm{CN}, 1.44 \mathrm{~g} \mathrm{HMD}$ and $0.35 \mathrm{~mL} \mathrm{AcOH}$ in $10 \mathrm{~mL}$ $\mathrm{DMF}$; after that, the temperature was raised to $90^{\circ} \mathrm{C}$ under stirring and adding small amounts of cyanoborohydride (0.4 g) and DEX10 (0.98 g) over 5 hours. The reaction mixture was left overnight to reach room temperature, following which the $\mathrm{pH}$ of the mixture was adjusted to 7 by adding dropwise a $10 \% \mathrm{HCl}$ solution using a $\mathrm{pH}$ meter inoLab 7110 . The reaction mixture was then loaded in a dialysis sack and dialyzed against water until negative reaction towards ninhydrin. In the dialysis sack, approximately $5 \mathrm{~mL}$ of $20 \% \mathrm{NH}_{3}$ solution was added and dialyzed against water until negative reaction towards the Nessler reagent.

The obtained solution was lyophilized $\left(-60^{\circ} \mathrm{C}\right)$ and the resulting product was loaded into a column with Amberlite IR-120 (acid form) resin. The unreacted maltodextrin was removed by elution with water and the aminated dextrin was removed by elution with a $2 \%$ ammonia solution. The basic eluates were combined and dialyzed against water until negative reaction towards Nessler reagent. The aminated maltodextrin HDEX-1600 was isolated by lyophilization (Alpha 1-2 Freeze Dryer (Christ), resulting a white powder (HDEX-1600).

Raw glycan - The extraction, isolation, purification and fractionation of the polysaccharide mixture from the fruiting body of Fomes fomentarius was previously described [4]. For the extraction step an aliquot of 300 g Fomes fomentarius powder (Vâlcea County, Romania) was extracted by refluxing using only hot water $(3 \times 1.5 \mathrm{~L})$ as a solvent, followed by evaporation of the solvent in a rotary evaporator RII (Buchi) at low pressure. The purification step yielded an amount of $128 \mathrm{mg}$ of beige-brownish powder after completing the following protocol: precipitation with absolute ethanol from aqueous solution, filtration, washing, dialysis against water and lyophilization.

\section{Column chromatography}

For fractionation of the polysaccharide mixture (45 mg in $5 \mathrm{~mL}$ eluent) $25 \times 3 \mathrm{~cm}$ columns filled with DEAE Sepharose Fast Flow were used. An additional purification step for the neutral and acidic fractions was performed in order to eliminate the salts from the samples by dialysis against water using membranes with $\mathrm{MW} / \mathrm{CO}=$ 1000, until negative reaction for $\mathrm{AgNO}_{3}$ was obtained. Then, the dialysate of the neutral polysaccharidic fractions was lyophilized once again giving $8 \mathrm{mg}$ of white powder. 


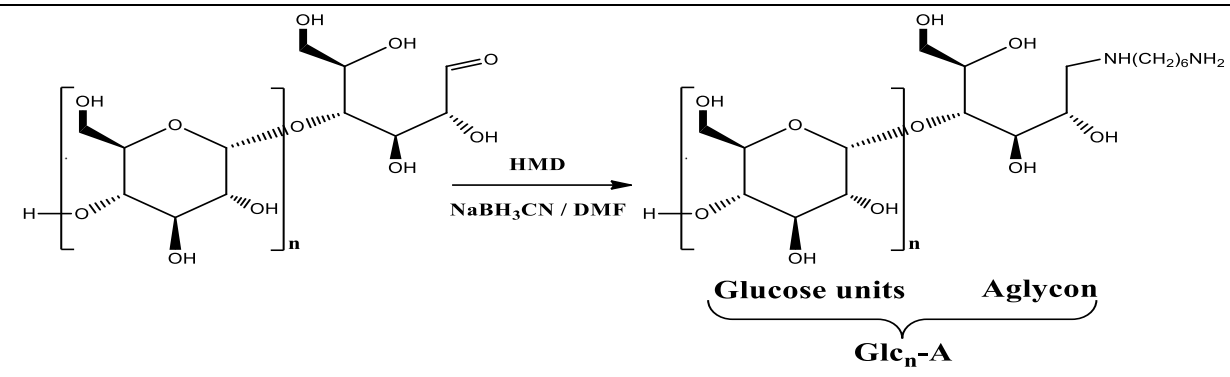

Figure 1.

Reductive amination of Dextrin 10 with hexamethylenediamine (HMD)

\section{Mass Spectrometry}

MALDI-TOF mass spectra of the samples were recorded by using a Bruker Ultraflextreme MALDI-TOF workstation controlled by FlexControl (Bruker Daltonics, Bremen, Germany) equipped with a Smartbeam II laser (Bruker Daltonics) of $355 \mathrm{~nm}$ and operating in positive mode. The following settings were used: laser frequency, 2,000 Hz; smartbeam, '4_large'; sample rate and digitizer settings, $1.25 \mathrm{GS} / \mathrm{sec}$; accelerator voltage, $20.07 \mathrm{kV}$; extraction voltage, $18.87 \mathrm{kV}$; lens voltage, $5.58 \mathrm{kV}$; and delayed extraction, $250 \mathrm{~ns}$. A 1,000 laser shots were used for each individual spectrum and minimum of 10 individual spectra were cumulated and saved. External calibration was performed using maltodextrin (Paselli MD-6, AVEBE, Veendam, The Netherlands). FlexAnalysis, version 3.3 (Bruker Daltonics) was spotted on MTP 384 polished steel BC targets (Bruker Daltonics). Samples were overlaid with 2,5-DHB (1 $\mu \mathrm{L}$ sol) and left for drying (dried droplet method). Matrix solubilization procedure included dissolution of 2,5-DHB $(20 \mathrm{mg} / \mathrm{mL})$ in acetonitrile $-0.1 \% \mathrm{HCOOH}$ in water $(30: 70 \mathrm{v} / \mathrm{v})$ supplemented with $0.5 \mu \mathrm{L}$ (1 mM TFA/MeOH).

UV spectrophotometry

Carbohydrates determinations using the $\mathrm{PhOH} / \mathrm{H}_{2} \mathrm{SO}_{4}$ method were performed on a Biochrom Libra S12 $\mathrm{UV} / \mathrm{V}$ is Spectrophotometer in $1 \mathrm{~cm}$ cuvettes at $\lambda=$ $490 \mathrm{~nm}$.

\section{Results and Discussion}

\section{Modified glycan}

The attachment of an aliphatic or aromatic amine by reductive amination at the reducing end of monosaccharides, oligosaccharides and glycans, in order to improve their detection in liquid chromatography separations, is a well-documented reaction [1]. The amino group was used for the covalent attachment of the 1,6 - hexamethylenediamine to the reducing end of the maltodextrines and dextran through reductive amination [18, 20, 21].

Dextrin 10, a maltodextrin from SERVA with a MW = 1620 was derivatized by reductive amination using
HMD as the amine component according to the protocol described in the experimental section. In contrast to the previous procedure, the working method was adapted in order to avoid the double reductive amination at both ends of HMD. For this purpose, both the glycan and $\mathrm{NaBH}_{3} \mathrm{CN}$ were added in small amounts over several hours (however, the entire amount of amine was added from the start). The reaction mixture, obtained after neutralization and cooling, was loaded directly into the dialysis bag. The HMD excess and the products resulted from the decomposition of unreacted $\mathrm{NaBH}_{3} \mathrm{CN}$, following acid treatment, are all eliminated, and only the reaction product HDEX1600 remains, which may be contaminated with the unreacted maltodextrin.

The separation took place by loading into a column filled with a cation-exchange resin $\left(\mathrm{H}^{+}\right.$form $)$and washing with deionized water until the content of a test tube $(3 \mathrm{~mL})$ showed positive reaction with a ninhydrin alcohol solution. The water elution was followed by another elution with $2 \% \mathrm{NH}_{3}$ to completely desorb the HDEX-1600. The basic eluates were combined, concentrated at low pressure and dialyzed against water. The resulting product was a maltodextrin functionalized with HMD (Figure 1).

Maltodextrins and dextrans functionalized with aliphatic and aromatic diamines were previously investigated using ESI-QTOF-MS, ESI FTICR MS and HCIT-MS $[18,20-22]$. The investigation of the structure of basic polysaccharides using MALDI-TOF-MS is very poorly illustrated in the literature, probably due to the particularities of using the most common matrices that happen to be acidic. Their role in obtaining a proper ionization in the particular case of aminoglycans has been widely discussed in a previous work, with the mention that the addition of the ionization promoters is compulsory to obtain an acceptable spectrum [4]. As a result of using various matrices and optimizing the ionization process, but also of using the DHB as matrix and $\mathrm{HCOOH}$ and TFA as ionization promoters, the spectra presented in Figure 2 (A-C) were obtained. 
FARMACIA, 2020, Vol. 68, 5
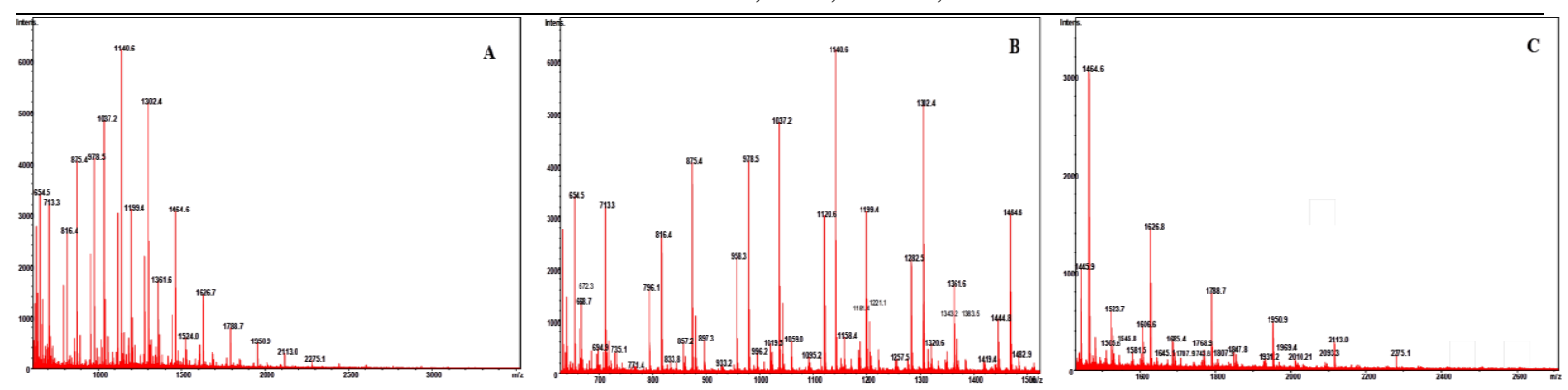

Figure 2.

Positive MALDI-TOF spectra of the HDEX-1600 sample (reflectron mode)

A) MS-spectrum m/z 600 - 3500; B) detail for $\mathrm{m} / \mathrm{z} 600$ - 1500; C) detail for $\mathrm{m} / \mathrm{z}=1500$ - 3500

The HMD derivatized dextrin, abbreviated as HDEX1600 , shows in its mass spectrum (recorded in positive and reflectron mode in the $\mathrm{m} / \mathrm{z} 600$ - 3500 domain) entire series of monosodiated and protonated ions $\left(\mathrm{M}+\mathrm{H}^{+}\right.$and $\left.\mathrm{M}+\mathrm{Na}^{+}\right)$, but only in the dehydrated form. The monosodiated ions are mono and, respectively, triple dehydrated, whereas the protonated ions are triple and tetra dehydrated.

Figures $2 \mathrm{~B}$ and $2 \mathrm{C}$ present in detail the intervals $m / z 600-1500$ and $m / z 1500-3500$ domains, allowing the clear observation of all peaks, while their assignment is presented in Table I.

Table I

Assignment of the major ions observed in positive MALDI TOF spectrum of the HDEX-1600 sample

\begin{tabular}{|c|c|c|c|c|c|c|c|}
\hline No. & $\mathrm{m} / \mathrm{z}$ & Charge & Assignments & Nr. & $m / z$ & Charge & Assignments \\
\hline 1. & 2437.1 & +1 & $\mathrm{~B}_{15}+\mathrm{Na}^{+}-\mathrm{H}_{2} \mathrm{O}$ & 31 & 1302.4 & +1 & $\mathrm{~B}_{8}+\mathrm{Na}^{+}-\mathrm{H}_{2} \mathrm{O}$ \\
\hline 2 & 2275.1 & +1 & $\mathrm{~B}_{14}+\mathrm{Na}^{+}-\mathrm{H}_{2} \mathrm{O}$ & 32 & 1282.5 & +1 & $\mathrm{C}_{8}+\mathrm{Na}^{+}-3 \mathrm{H}_{2} \mathrm{O}$ \\
\hline 3 & 2113.0 & +1 & $\mathrm{~B}_{13}+\mathrm{Na}^{+}-\mathrm{H}_{2} \mathrm{O}$ & 33 & 1257.5 & +1 & $\left(\mathrm{Glc}_{6} \mathrm{~A}\right)+\mathrm{Na}^{+}-\mathrm{H}_{2} \mathrm{O}$ \\
\hline 4 & 2093.3 & +1 & $\mathrm{C}_{13}+\mathrm{Na}^{+}-3 \mathrm{H}_{2} \mathrm{O}$ & 34 & 1199.4 & +1 & $\mathrm{Glc}_{6} \mathrm{~A}+\mathrm{H}^{+}-3 \mathrm{H}_{2} \mathrm{O}$ \\
\hline 5 & 2010.1 & +1 & $\mathrm{Glc}_{11} \mathrm{~A}+\mathrm{H}^{+}-3 \mathrm{H}_{2} \mathrm{O}$ & 35 & 1181.4 & +1 & $\mathrm{Glc}_{6} \mathrm{~A}+\mathrm{H}^{+}-4 \mathrm{H}_{2} \mathrm{O}$ \\
\hline 6 & 1969.4 & +1 & $\mathrm{~B}_{12}+\mathrm{Na}^{+}$ & 36 & 1158.4 & +1 & $\mathrm{~B}_{7}+\mathrm{Na}^{+}$ \\
\hline 3 & 1950.9 & +1 & $\mathrm{~B}_{12}+\mathrm{Na}^{+}-\mathrm{H}_{2} \mathrm{O}$ & 37 & 1140.6 & +1 & $\mathrm{~B}_{7}+\mathrm{Na}^{+}-\mathrm{H}_{2} \mathrm{O}$ \\
\hline 7 & 1931.2 & +1 & $\mathrm{C}_{12}+\mathrm{Na}^{+}-3 \mathrm{H}_{2} \mathrm{O}$ & 38 & 1120.6 & +1 & $\mathrm{C}_{7}+\mathrm{Na}^{+}-3 \mathrm{H}_{2} \mathrm{O}$ \\
\hline 8 & 1906.1 & +1 & $\left(\mathrm{Glc}_{10} \mathrm{~A}\right)+\mathrm{Na}^{+}-\mathrm{H}_{2} \mathrm{O}$ & 39 & 1095.2 & +1 & $\left(\mathrm{Glc}_{5} \mathrm{~A}\right)+\mathrm{Na}^{+}-\mathrm{H}_{2} \mathrm{O}$ \\
\hline 9 & 1847.8 & +1 & $\mathrm{Glc}_{10} \mathrm{~A}+\mathrm{H}^{+}-3 \mathrm{H}_{2} \mathrm{O}$ & 40 & 1059.0 & +1 & $\mathrm{Glc}_{5} \mathrm{~A}+\mathrm{Na}^{+}-3 \mathrm{H}_{2} \mathrm{O}$ \\
\hline 10 & 1807.3 & +1 & $\mathrm{~B}_{11}+\mathrm{Na}^{+}$ & 41 & 1037.2 & +1 & $\mathrm{Glc}_{5} \mathrm{~A}+\mathrm{H}^{+}-3 \mathrm{H}_{2} \mathrm{O}$ \\
\hline 11 & 1788.7 & +1 & $\mathrm{~B}_{11}+\mathrm{Na}^{+}-\mathrm{H}_{2} \mathrm{O}$ & 42 & 1019.5 & +1 & $\mathrm{Glc}_{5} \mathrm{~A}+\mathrm{H}^{+}-4 \mathrm{H}_{2} \mathrm{O}$ \\
\hline 12 & 1768.9 & +1 & $\mathrm{C}_{11}+\mathrm{Na}^{+}-3 \mathrm{H}_{2} \mathrm{O}$ & 43 & 996.2 & +1 & $\mathrm{~B}_{6}+\mathrm{Na}^{+}$ \\
\hline 13 & 1743.8 & +1 & $\left(\mathrm{Glc}_{9} \mathrm{~A}\right)+\mathrm{Na}^{+}-\mathrm{H}_{2} \mathrm{O}$ & 44 & 978.5 & +1 & $\mathrm{~B}_{6}+\mathrm{Na}^{+}-\mathrm{H}_{2} \mathrm{O}$ \\
\hline 14 & 1707.9 & +1 & $\mathrm{Glc}_{9} \mathrm{~A}+\mathrm{Na}^{+}-3 \mathrm{H}_{2} \mathrm{O}$ & 45 & 958.3 & +1 & $\mathrm{C}_{6}+\mathrm{Na}^{+}-3 \mathrm{H}_{2} \mathrm{O}$ \\
\hline 15 & 1685.4 & +1 & $\mathrm{Glc}_{9} \mathrm{~A}+\mathrm{H}^{+}-3 \mathrm{H}_{2} \mathrm{O}$ & 46 & 933.2 & +1 & $\left(\mathrm{Glc}_{4} \mathrm{~A}\right)+\mathrm{Na}^{+}-\mathrm{H}_{2} \mathrm{O}$ \\
\hline 16 & 1645.1 & +1 & $\mathrm{~B}_{10}+\mathrm{Na}^{+}$ & 47 & 897.3 & +1 & $\mathrm{Glc}_{4} \mathrm{~A}+\mathrm{Na}^{+}-3 \mathrm{H}_{2} \mathrm{O}$ \\
\hline 17 & 1626.8 & +1 & $\mathrm{~B}_{10}+\mathrm{Na}^{+}-\mathrm{H}_{2} \mathrm{O}$ & 48 & 875.4 & +1 & $\mathrm{Glc}_{4} \mathrm{~A}+\mathrm{H}^{+}-3 \mathrm{H}_{2} \mathrm{O}$ \\
\hline 18 & 1606.6 & +1 & $\mathrm{C}_{10}+\mathrm{Na}^{+}-3 \mathrm{H}_{2} \mathrm{O}$ & 49 & 857.2 & +1 & $\mathrm{Glc}_{4} \mathrm{~A}+\mathrm{H}^{+}-4 \mathrm{H}_{2} \mathrm{O}$ \\
\hline 19 & 1581.5 & +1 & $\left(\mathrm{Glc}_{8} \mathrm{~A}\right)+\mathrm{Na}^{+}-\mathrm{H}_{2} \mathrm{O}$ & 50 & 833.8 & +1 & $\mathrm{~B}_{5}+\mathrm{Na}^{+}$ \\
\hline 20 & 1545.8 & +1 & $\mathrm{Glc}_{8} \mathrm{~A}+\mathrm{Na}^{+}-3 \mathrm{H}_{2} \mathrm{O}$ & 60 & 816.4 & +1 & $\mathrm{~B}_{5}+\mathrm{Na}^{+}-\mathrm{H}_{2} \mathrm{O}$ \\
\hline 21 & 1523.7 & +1 & $\mathrm{Glc} 8 \mathrm{~A}+\mathrm{H}^{+}-3 \mathrm{H}_{2} \mathrm{O}$ & 61 & 796.1 & +1 & $\mathrm{C}_{5}+\mathrm{Na}^{+}-3 \mathrm{H}_{2} \mathrm{O}$ \\
\hline 22 & 1505.6 & +1 & $\mathrm{Glc}_{8} \mathrm{~A}+\mathrm{H}^{+}-4 \mathrm{H}_{2} \mathrm{O}$ & 62 & 771.4 & +1 & $\left(\mathrm{Glc}_{3} \mathrm{~A}\right)+\mathrm{Na}^{+}-\mathrm{H}_{2} \mathrm{O}$ \\
\hline 23 & 1482.9 & +1 & $\mathrm{~B}_{9}+\mathrm{Na}^{+}$ & 63 & 735.1 & +1 & $\mathrm{Glc}_{3} \mathrm{~A}+\mathrm{Na}^{+}-3 \mathrm{H}_{2} \mathrm{O}$ \\
\hline 24 & 1464.6 & +1 & $\mathrm{~B}_{9}+\mathrm{Na}^{+}-\mathrm{H}_{2} \mathrm{O}$ & 64 & 713.3 & +1 & $\mathrm{Glc}_{3} \mathrm{~A}+\mathrm{H}^{+}-3 \mathrm{H}_{2} \mathrm{O}$ \\
\hline 25 & 1444.8 & +1 & $\mathrm{C}_{9}+\mathrm{Na}^{+}-3 \mathrm{H}_{2} \mathrm{O}$ & 65 & 694.9 & +1 & $\mathrm{Glc}_{3} \mathrm{~A}+\mathrm{H}^{+}-4 \mathrm{H}_{2} \mathrm{O}$ \\
\hline 26 & 1419.4 & +1 & $\left(\mathrm{Glc}_{7} \mathrm{~A}\right)+\mathrm{Na}^{+}-\mathrm{H}_{2} \mathrm{O}$ & 66 & 672.3 & +1 & $\mathrm{~B}_{4}+\mathrm{Na}^{+}$ \\
\hline 27 & 1383.5 & +1 & $\mathrm{Glc}_{7} \mathrm{~A}+\mathrm{Na}^{+}-3 \mathrm{H}_{2} \mathrm{O}$ & 67 & 654.5 & +1 & $\mathrm{~B}_{4}+\mathrm{Na}^{+}-\mathrm{H}_{2} \mathrm{O}$ \\
\hline 28 & 1361.6 & +1 & $\mathrm{Glc}_{7} \mathrm{~A}+\mathrm{H}^{+}-3 \mathrm{H}_{2} \mathrm{O}$ & 68 & 634.3 & +1 & $\mathrm{C}_{4}+\mathrm{Na}^{+}-3 \mathrm{H}_{2} \mathrm{O}$ \\
\hline 29 & 1343.2 & +1 & $\mathrm{Glc}_{7} \mathrm{~A}+\mathrm{H}^{+}-4 \mathrm{H}_{2} \mathrm{O}$ & 69 & 609.2 & +1 & $\left(\mathrm{Glc}_{2} \mathrm{~A}\right)+\mathrm{Na}^{+}-\mathrm{H}_{2} \mathrm{O}$ \\
\hline 30 & 1320.6 & +1 & $\mathrm{~B}_{8}+\mathrm{Na}^{+}$ & & & & \\
\hline
\end{tabular}

The significance of fragments $B_{\mathbf{n}}$ and $\mathrm{C}_{\mathbf{n}}$, respectively, are in concordance with the Domon and Costello convention [7]. Both the $B_{n}$ and $C_{n}$ series are present as the dehydrated monosodiated form (mono-dehydrated and triple-dehydrated, respectively). Under the chosen working conditions no potassiated positive ions were observed. The maximum degree of polymerization detected by MALDI-TOF-MS for HDEX-1600 was 11. Raw glycan 
Plant glycans exhibit a number of beneficial therapeutic properties, and it is thought that the mechanisms involved in these effects are due to the modulation of innate immunity and, more specifically, of the macrophage function [23]. Numerous medicinal resources and antitumor substances were identified in many mushroom species, of which polysaccharides are the best known and the most potent mushroom derived substances with antitumor and immunomodulation properties. The isolation, structural characterization and antitumor activity of mushroom polysaccharides have been extensively investigated in the past three decades [24].

The isolation, separation and purification of polysaccharides from the fruiting bodies of Fomes fomentarius were the subject of research in the '70s $[2,3,16]$. The authors used hot extraction of polysaccharides with water, alkaline solutions $(\mathrm{NaOH})$ or acid solutions. Regardless of the protocol used, the resulting raw mixture of polysaccharides was further fractionated on DEAE Cellullose [2, 3] or was subjected to a more elaborated procedure: fractionation on DEAE Cellulose, fractional precipitation with CTA-Br (cetyltrimethyl-ammonium bromide) and separation on DOWEX IX8 columns [16].

The separation of neutral and acidic polysaccharides was followed by exhaustive methylation, acid hydrolysis and reduction, and finally by exhaustive acetylation. The methylated and acetylated polyols were separated and identified by GC-MS using standard references.
More recently [19], the extraction, purification and separation of polysaccharides from Fomes fomentarius were studied for the purpose of testing their immunomodulatory capacity and the schematic diagram depicting the isolation process of water extractable polysaccharides from the fruiting bodies of Fomes fomentarius inspired us in our strategy for isolation and characterization.

Thus, a sample of the polysaccharide raw mixture was loaded after extraction and purification (see experimental) and eluted in a column of Sepharose FF (Sepharose Fast Flow is an ion exchange medium consisting of macroporous, beaded, cross-linked agarose to which diethylaminoethyl groups are attached).

In the first stage, during elution with a $0.01 \mathrm{M}$ Tris solution adjusted to $\mathrm{pH} \mathrm{7,} \mathrm{the} \mathrm{migration} \mathrm{of} \mathrm{neutral}$ polysaccharides (NPi) takes place, after which, during elution with $\mathrm{NaCl}(0.1 \mathrm{M}, 0.4 \mathrm{M}$ and $1 \mathrm{M}$ respectively), the elution of acid polysaccharides (APi) occurs. The eluates were tested for the presence of carbohydrates using the $\mathrm{PhOH} / \mathrm{H}_{2} \mathrm{SO}_{4}$ method according to a wellestablished protocol [5]. Graphical representation of the absorbance measured at $\lambda=490 \mathrm{~nm}$ as a function of the number of fractions leads to an "elution profile", which is shown in Figure 3. The tubes containing the polysaccharides were combined, dialyzed and lyophilized. The IR spectra of the three fractions $\mathrm{NP}_{\mathbf{1}}$, $\mathrm{NP}_{2}$ and $\mathrm{NP}_{3}$ does not reveal the valence vibration of the carbonyl group within the $1700-1800 \mathrm{~cm}^{-1}$ domain.

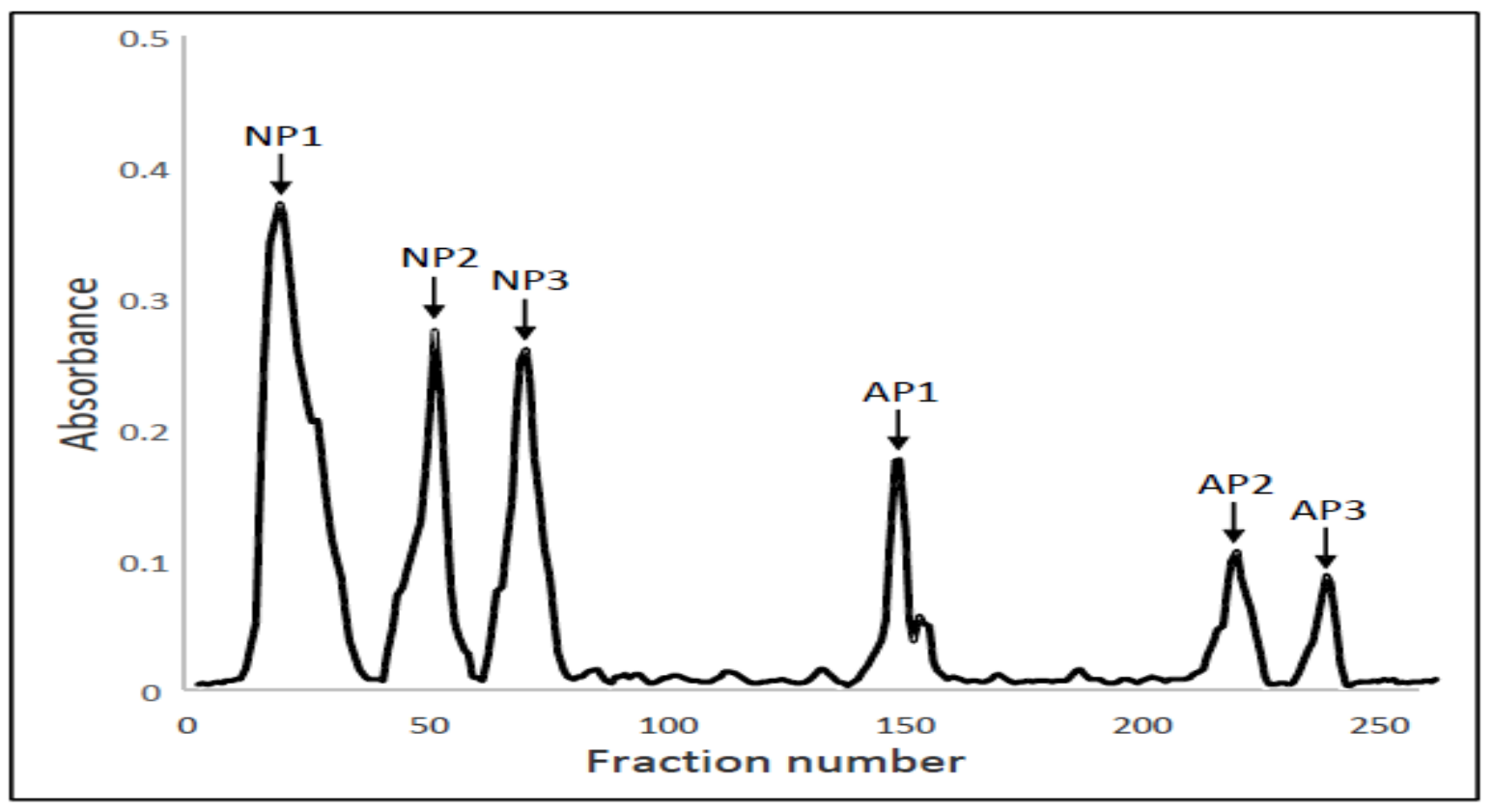

Figure 3.

Elution profiles of crude polysaccharides on DEAE-sepharose FF column $(25 \times 3 \mathrm{~cm})$

$\mathrm{NP}_{\mathbf{i}}=$ neutral polysaccharides; $\mathrm{APi}=$ acidic polysaccharides; the column was equilibrated with $10 \mathrm{mM}$ Tris- $\mathrm{HCl}$ buffer $(\mathrm{pH}$ 7.0), than eluted as follows: a) $1-100$ tube $10 \mathrm{mM}$ Tris- $\mathrm{HCl}$ buffer; b) $101-175$ tube with $0.1 \mathrm{M} \mathrm{NaCl}$ in $10 \mathrm{mM}$ Tris-HCl; c) 176 - 230 tube with $0.4 \mathrm{M} \mathrm{NaCl}$ in $10 \mathrm{mM}$ Tris-HCl; d) 231 - 300 tube with $1.0 \mathrm{M} \mathrm{NaCl}$ in $10 \mathrm{mM}$ Tris- $\mathrm{HCl}\left(\mathrm{A}_{\lambda}=490 \mathrm{~nm}\right)$ 
It was thus concluded that these polysaccharides contain neither the free, nor the esterified carboxyl groups, nor any acyl fragments. Thus, the three fractions represent neutral polysaccharides (NPi). The spectra analysis shows that the peaks are separated by a $162 \mathrm{Da}$ step, indicating that there is a glycan composed from of at least one hexose unit. The absence of a 146 Da difference between any two consecutive peaks indicates that the glycan does not contain fucose or rhamnose as it was shown in literature $[2,3,16]$. Finally, a sample of each NPi was subjected to acid hydrolysis followed by neutralization. The TLC analyses of the hydrolysates from NP1, NP2 and NP3 lead to the conclusions the fructose is absent from the studies samples.

Assignment of the major ions observed in positive MALDI-TOF spectrum of the NP1-FF sample

\begin{tabular}{|c|c|c|c|c|c|c|c|}
\hline No. & $\mathrm{m} / \mathrm{z}$ & Charge & Assignments & Nr. & $\mathrm{m} / \mathrm{z}$ & Charge & Assignments \\
\hline 1 & 3614.2 & +1 & $\mathrm{Hex} 22+\mathrm{Na}^{+}$ & 21 & 1679.1 & +1 & $\mathrm{Hex} 10+\mathrm{K}^{+}$ \\
\hline 2 & 3452.1 & +1 & $\mathrm{Hex} 21+\mathrm{Na}^{+}$ & 22 & 1663.0 & +1 & $\mathrm{Hex} 10+\mathrm{Na}^{+}$ \\
\hline 3 & 3288.5 & +1 & $\mathrm{Hex} 20+\mathrm{Na}^{+}$ & 23 & 1645.1 & +1 & $\mathrm{Hex} 10+\mathrm{Na}^{+}-\mathrm{H}_{2} \mathrm{O}$ \\
\hline 4 & 3126.0 & +1 & $\mathrm{Hex} 19+\mathrm{Na}^{+}$ & 24 & 1516.6 & +1 & $\operatorname{Hex} 9+\mathrm{K}^{+}$ \\
\hline 5 & 2963.5 & +1 & $\mathrm{Hex} 18+\mathrm{Na}^{+}$ & 25 & 1500.7 & +1 & $\mathrm{Hex} 9+\mathrm{Na}^{+}$ \\
\hline 6 & 2801.0 & +1 & $\mathrm{Hex} 17+\mathrm{Na}^{+}$ & 26 & 1482.6 & +1 & $\mathrm{Hex} 9+\mathrm{Na}^{+}-\mathrm{H}_{2} \mathrm{O}$ \\
\hline 7 & 2638.5 & +1 & $\mathrm{Hex} 16+\mathrm{Na}^{+}$ & 27 & 1354.3 & +1 & $\mathrm{Hex} 8+\mathrm{K}^{+}$ \\
\hline 8 & 2619.4 & +1 & $\mathrm{Hex} 16+\mathrm{Na}-\mathrm{H}_{2} \mathrm{O}$ & 28 & 1338.3 & +1 & $\mathrm{Hex} 8+\mathrm{Na}^{+}$ \\
\hline 9 & 2475.0 & +1 & $\mathrm{Hex} 15+\mathrm{Na}^{+}$ & 29 & 1320.3 & +1 & $\mathrm{Hex} 8+\mathrm{Na}^{+}-\mathrm{H}_{2} \mathrm{O}$ \\
\hline 10 & 2458.0 & +1 & $\mathrm{Hex} 15+\mathrm{Na}^{+}-\mathrm{H}_{2} \mathrm{O}$ & 30 & 1175.8 & +1 & $\mathrm{Hex} 7+\mathrm{Na}^{+}$ \\
\hline 11 & 2312.6 & +1 & Hex $14+\mathrm{Na}^{+}$ & 31 & 1029.7 & +1 & Hex $6+\mathrm{K}^{+}$ \\
\hline 12 & 2294.6 & +1 & $\mathrm{Hex} 14+\mathrm{Na}^{+}-\mathrm{H}_{2} \mathrm{O}$ & 32 & 1013.7 & +1 & $\mathrm{Hex} 6+\mathrm{Na}^{+}$ \\
\hline 13 & 2150.2 & +1 & $\mathrm{Hex} 13+\mathrm{Na}^{+}$ & 33 & 995.7 & +1 & $\mathrm{Hex} 6+\mathrm{Na}^{+}-\mathrm{H}_{2} \mathrm{O}$ \\
\hline 14 & 2132.1 & +1 & $\mathrm{Hex} 13+\mathrm{Na}^{+}-\mathrm{H}_{2} \mathrm{O}$ & 34 & 867.5 & +1 & Hex $5+\mathrm{K}^{+}$ \\
\hline 15 & 2004.8 & +1 & $\operatorname{Hex} 12+\mathrm{K}^{+}$ & 35 & 851.5 & +1 & $\mathrm{Hex} 5+\mathrm{Na}^{+}$ \\
\hline 16 & 1987.8 & +1 & $\mathrm{Hex} 12+\mathrm{Na}^{+}$ & 36 & 833.4 & +1 & $\mathrm{Hex} 5+\mathrm{Na}^{+}-\mathrm{H}_{2} \mathrm{O}$ \\
\hline 17 & 1969.7 & +1 & $\mathrm{Hex} 12+\mathrm{Na}^{+}-\mathrm{H}_{2} \mathrm{O}$ & 37 & 745.7 & +1 & No assign \\
\hline 18 & 1841.4 & +1 & $\operatorname{Hex} 11+\mathrm{K}^{+}$ & 38 & 717.6 & +1 & No assign \\
\hline 19 & 1825.4 & +1 & $\mathrm{Hex} 11+\mathrm{Na}^{+}$ & 39 & 689.2 & +1 & $\mathrm{Hex} 4+\mathrm{Na}^{+}$ \\
\hline 20 & 1807.3 & +1 & $\mathrm{Hex} 11+\mathrm{Na}^{+}-\mathrm{H}_{2} \mathrm{O}$ & & & & \\
\hline
\end{tabular}

The chromatogram clearly indicates that the separated NP1 fraction is composed of a heteroglycan containing only hexoses (galactose and mannose). Details regarding the hydrolysis and the chromatographic and densitometric evaluation of the NP2 fraction are previously reported [4] The assignment of all peaks from the polysaccharides mass spectrum corresponding to NP1 fraction is given in Table II. Detailed analyses of all peaks in the MS1 (+)MALDI TOF spectra of the NP2 and NP3 fractions lead to the same conclusions and can be obtained on request. At this stage of our research we can state that a new $\left[\mathrm{Gal}_{\mathrm{x}} \mathrm{Man}_{\mathrm{y}}\right]_{\mathrm{n}}$ glycan (linear or branched) was discovered in Fomes fomentarius which does not contain fucose as it was previously reported in other papers from previous studies on Fomes fomentarius polysaccharides [2, 3, 16].

\section{Conclusions}

The preparation through reductive amination of a maltodextrin functionalized with an amine linker, in the minimum possible number of steps and with the maximum possible yield is presented. Isolation and purification of the basic glycan was also described. The extraction, isolation and purification of a neutral polysaccharide from the fruiting body of Fomes fomentarius, by combining ion exchange chromatography with dialysis, were described. Both the natural polysaccharide isolated from the mushroom and the glycan functionalized with hexamethylenediamine (HMD) were analysed by MALDI-TOF mass spectrometry in the positive ion mode. By combining the chemical methods, TLC and mass spectrometry, the existence of a new neutral heteropolysaccharide $\left[\mathrm{Gal}_{\mathrm{x}} \mathrm{Man}_{\mathrm{y}}\right]_{\mathbf{n}}$ in the Fomes fomentarius polysaccharides fractions was revealed.

\section{Acknowledgement}

This work was supported by the Romanian National Authority for Scientific Research (CNCS-UEFISCDI) through project PN-II-PCCA-2011-142. Part of the research was done at the Centre of Genomic Medicine from the "Victor Babes" University of Medicine and Pharmacy of Timișoara, POSCCE 185/48749, contract 677/09.04.2015.

\section{Conflict of interest}

The authors declare no conflict of interest.

\section{References}

1. Baxter EW, Reitz AB, Reductive aminations of carbonyl compounds with borohydride and borane reducing agents. Org React., 2001; 59: 1-714. 
2. Bjorndal H, Lindberg B, Polysaccharides elaborated by Polyporus fomentarius and Polyporus igniarius Part I. Water-soluble neutral polysaccharides from the fruit bodies. Carbohydr Res., 1969; 10: 79-85.

3. Bjorndal H, Lindberg B, Polysaccharides elaborated by Polyporus fomentarius (Fr.) and Polyporus igniarius (Fr.) Part II. Water-soluble, acidic polysaccharides from the fruit bodies. Carbohydr Res., 1970; 12: 29-35.

4. Bojin L, Cojocaru C, Georgescu M, Puiu M, Pascariu MC, Serb A, Puscasiu D, Tatu C, Sisu E, Investigation of neutral polysaccharides from Fomes fomentarius. A preliminary study. Fiziologia Physiology, 2018; 28.2(96): 20-27.

5. Chaplin FM, Monosaccharides, in Carbohydrate Analysis. A Practical Approach. Ed. Chaplin MF and Kennedy JK, IRL Press, Oxford, 1994: 1-37.

6. Cumpstey I, Chemical modification of polysaccharides. ISRN Org Chem., 2013; 2013: 1-27.

7. Domon B, Costello CE, A systematic nomenclature for carbohydrate fragmentations in FAB-MS/MS spectra of glycoconjugates. Glycoconjugate Journal, 1988; 5(4): 397-409.

8. Gopinath V, Saravanan S, Al-Maleki AR, Ramesh M, Vadivelu J, A review of natural polysaccharides for drug delivery applications: special focus on cellulose, starch and glycogen. Biomed Pharmacother., 2018; 107: 96-108.

9. Harvey DJ, Matrix-assisted laser desorption/ionization mass spectrometry of carbohydrates. Mass Spectrom Rev., 1999; 18(6): 349-450.

10. Ioanoviciu SD, Ivan C, Matusz P, Olariu S, Lighezan $\mathrm{D}$, Morphological variability of the hepatic portal vein posterior branch: study on corrosion casts. Mater Plast., 2015; 52(2): 263-265.

11. Ivan C, Nica CC, Dobrescu A, Belic O, Matusz P, Olariu S, Using human intrahepatic bile duct system corrosion casts in training of the medical students and residents. Mater Plast., 2015, 52(1): 48-50.

12. Ivan VM, Georgescu M, Apostol A, Albulescu N, Serb AF, Tatu CS, Trimetazidine, a metabolic modulator, with cardioprotective effects against myocardial ischemia. Rev Chim (Bucharest), 2018; 69(7): 1616-1620.

13. Karas M, Hillenkamp F, Laser desorption ionization of proteins with molecular masses exceeding 10,000 daltons. Anal Chem., 1988; 60(20): 2299-2301.

14. Karas M, Bachmann D, Hillenkamp F, Influence of the wavelength in high-irradiance ultraviolet laser desorption mass spectrometry of organic molecules. Anal Chem., 1985; 57(14): 2935-2939.

15. Karas M, Bachmann D, Bahr U, Hillenkamp F, Matrix-assisted ultraviolet laser desorption of nonvolatile compounds. Int J Mass Spectrom., 1987; 78: 53-68.

16. Kardošová A, Babor $\mathrm{K}$, Rosík J, Kubala J, Polysaccharides of wood-destroying fungus Fomes fomentarius extracted with water. Chemické Zvest., 1969; 23(6): 454-461.

17. Liu J, Willfor $\mathrm{S}$, Xun C, A review of bioactive plant polysaccharides: biological activities, functionalization, and biomedical applications. Bioact Carbohydr Diet Fibre., 2015; 5: 31-61.

18. Perdivara I, Sisu E, Sisu I, Dinca N, Tomer KB, Przybylski M, Zamfir AD, Enhanced electrospray ionization Fourier transform ion cyclotron resonance mass spectrometry of long-chain polysaccharides. Rapid Commun Mass Spectrom., 2008; 22: 773-782.

19. Park JK, Park KW, Shin KS, Lee CM, Seok SJ, Kim JB, Koo BS, Han BS, Yoon SH, Isolation and chemical analysis of potent anti-complementary polysaccharides from fruiting bodies of the Fomes fomentarius. Korean J Microbiol Biotechn., 2013; 41(2): 198-206.

20. Sisu E, Bosker WTE, Norde W, Slaghek TM, Timmermans JW, Peter-Katalinic J, Cohen-Stuart $\mathrm{MA}$, Zamfir AD, Electrospray ionization quadrupole time-of-flight tandem mass spectrometric analysis of hexamethylenediamine-modified maltodextrin and dextran. Rapid Commun Mass Spectrom., 2005; 20(2): 209-218.

21. Sisu I, Udrescu V, Flangea C, Tudor S, Dinca N, Rusnac L, Zamfir A, Sisu E, Synthesis and structural characterization of maltodextrins functionalized with hexamethylenediamine. Cent Eur J Chem., 2009; 7(1): 66-73.

22. Sisu I, Sisu E, Simu GM, Modified polysaccharides with azoic chromophores 1 . Hydrophylic diaminodiphenil methane dye. Rev Roum Chim., 2011; 56(5): 527-553.

23. Schepetkin IA, Quinn MT, Botanical polysaccharides: macrophage immuno-modulation and therapeutic potential. Int Immunopharmacol., 2006; 6: 317-333.

24. Zhang M, Cui SW, Cheung PCK, Wang Q, Antitumor polysaccharides from mushrooms: a review on their isolation process, structural characteristics and antitumor activity. Trends Food Sci Technol., 2007; 18(1): 4-19. 